\title{
IMPACT OF HERITAGE ON CONTEMPORARY SUSTAINABLE INTERIOR DESIGN SOLUTIONS
}

\author{
WAEL RASHDAN \& VRUSHALI MHATRE \\ Interior Design Department, College of Architecture and Design, Al Ghurair University, UAE
}

\begin{abstract}
Vernacular interior design consists of spaces that affirm a unique material, have affinity with the local region, and carries the potential to create a sustainable, harmonious relationship between humans, nature, and the built environment. In the United Arab Emirates (UAE), sustainable interior design concepts were inherited from vernacular to modern spaces. Despite the abundance of research on sustainable design, few studies have addressed the relationship between vernacular and modern sustainable interior design solutions. Studies on heritage-based interior design solutions indicate the potential to extend and implement traditional concepts into contemporary design. Hence, the objective of this research is to identify the major elements of vernacular sustainable design in the UAE and measure its applicability to contemporary interior design solutions. This paper explores some examples that reflect the impact of the country's heritage on contemporary sustainable interior design, concluding that sustainable concepts in heritage design may inspire contemporary interior designers to reflect on the effectiveness of traditional design solutions.
\end{abstract}

Keywords: interior design, sustainability, sustainable interior design, vernacular sustainable solutions, vernacular interior design.

\section{INTRODUCTION}

Vernacular design helps create a community identity and develop a sense of belonging. It is an expression of people's beliefs, lifestyles, creative abilities, traditions, cultures, aspirations, needs, and futures [1], [2]. Vernacular design is related to the concept of localization, in which individual designs are inspired by the surrounding nature, utilize local materials and traditional construction methods, and respect the geographical and climate features of the region [3]. As a result, vernacular products have achieved much success in expressing the identity of a community and maintaining the lifestyles and wellbeing of occupants [2], [4]. The vernacular design process evolves in combination with natural and cultural factors, resulting in the embeddedness of a wide variety of sustainable ecosystems in heritage-based building designs. These traditional sustainable design solutions serve as evidence of the interaction between the natural and anthropogenic environment [5], [6]. Designers develop sustainable concepts when they merge new sustainable technologies with extant heritage systems [7], [8]. This combination can preserve the local identity while achieving an effective sustainable solution that emerges from the surrounding environment [6]. There are several examples of this design practice around the world. The present paper argues that merging traditional applications with contemporary design concepts can positively influence sustainability in the built environment. Different elements of traditional sustainable solutions in the vernacular interior design of the United Arab Emirates (UAE) will be explored and discussed for its characteristics. This paper also analyzes examples of merging the principles of traditional sustainable concepts in contemporary design as they appear in UAE heritage buildings. 


\section{SUSTAINABILITY IN THE UNITED ARAB EMIRATES}

\subsection{Sustainable design between heritage and modernity}

UAE heritage buildings represent many of the vernacular sustainable design solutions within the country. Historically, the vernacular approach to design has included the combination of three major factors, including: the hot and humid climate; the people, religion, and traditions; and the locally available building materials [9], [10]. Climate is a major component that influences occupant behaviors, building forms, and architectural appearance to reach an adequate level of comfort [11]. The lead designer's duty is to employ various tools, methods, and natural resources in an innovative manner to provide ventilation and thermal comfort in arid climates [12], [13].

Over the last decade, the UAE has experienced a spectacular amount of change. Its dynamic cities, such as Abu Dhabi and Dubai, illustrate how far the country has come from hosting modest to iconic contemporary cities [14]. The UAE holds sustainable development in high regard, considering it a way of life for the country [15]. Its "Green Building Regulations and Specifications" has been a mandatory guideline in the design of all new buildings since 2014. Largescale projects have already emerged to achieve this goal, such as "MASDAR" city in Abu Dhabi and the "Sustainable City" in Dubai, which is a new district planned at a more sustainable scale [16]. These examples show that the UAE has set its sights on becoming a global leader in sustainability.

\subsection{Vernacular sustainable design solutions}

The term "vernacular design" refers to local buildings that have grown in the fullness of time in one locality [2]. Vernacular design solutions are developed in response to the constraints of climate, materials, and cultural factors in a particular location, identified through countless experiments, miscalculations, and innovations by local builders who have extensive knowledge and experience concerning the location [3], [17]. Hence, vernacular design solutions include data that is essential to optimizing the energy efficiency of buildings at minimal cost through the use of local materials [9].

The rising phenomena of globalization and increased energy costs require significant transformations in building design attitudes, methods, and construction procedures. The improvement of new, healthy, and comfortable prototypes of exceptionally sustainable buildings is a crucial foundation in the development of future buildings [18].

Designers can gain significant knowledge from vernacular solutions when designing modern prototypes; however, they cannot be easily applied without considering the consequences of operating in a local context [13]. It is important to recognize and use characteristics observed from vernacular architecture when designing modern buildings. The following literature review discusses the sustainable development methods and techniques observed among vernacular buildings in Dubai, as well as and their application in contemporary designs across the UAE.

\subsubsection{Wind towers}

A wind tower ("wind catcher" or "Barjeel") is a traditional tower designed and mounted on the roof of a building [19]. Wind towers are not only a decorative element but are also highly functional, playing a considerable role in the cooling and ventilation of traditional buildings, thus providing thermal comfort for inhabitants in a natural way that does not use energy [20], [21]. Consequently, wind towers have enjoyed widespread use in the traditional 
architecture of the Gulf region, particularly in Dubai and Bahrain [22]. Early wind towers in Dubai were built from palm trunks and leaves called Areesh, but were eventually developed from coral (Fig. 1).

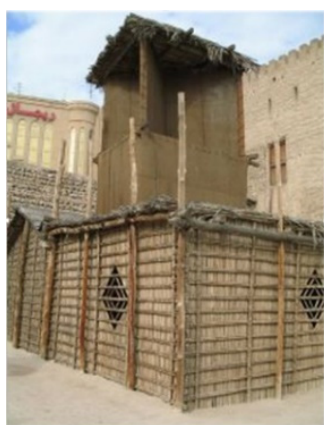

(a)

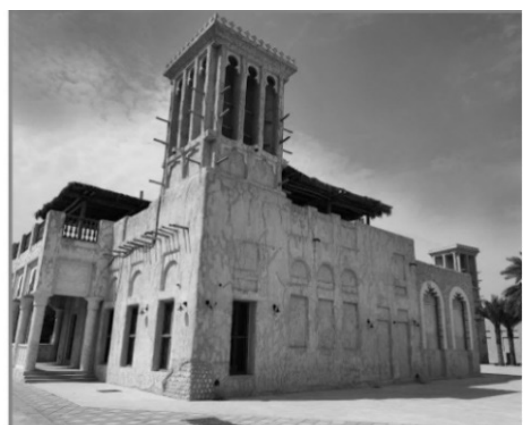

(b)

Figure 1: Traditional wind towers in Dubai. (a) Areesh wind tower; and (b) Coral wind tower. (Source: Authors, 2019.)

The wind tower is an essential element of vernacular buildings built in hot climates, used to capture wind at a higher elevation and direct it into the inner environment of a building [19]. Traditional wind towers consist of several components, including openings, a roof, a head, a channel, and internal partitions [23]. These are combined to form a hollow square tower that catches the wind from any direction, creating an air stream into the tower's shaft that helps ventilate the occupied building space [24]. They come in various designs: unidirectional, bi-directional, and multi-directional [25]. Generally, they are categorized into five groups, including one-, two-, four-, six- and eight-sided towers, as well as cylindrical towers [26]. Although wind towers do not have a standard design or dimension, they are typically designed to fit the local climate conditions. In the tremendously hot climates of the Gulf region, wind towers are exceptionally large and often attached to ventilated parapets and walls to move as much air as possible throughout the interior [12].

Wind towers allow hot air (less dense) to rise out of the top and escape through its exhaust channels, while cooler winds flow down into the home to replace the air that escaped [27]. The operational principles of wind towers are based on pressure differences, which vary from morning to evening. In the morning, a positive pressure on the windward side and negative pressure on the leeward side are produced via the movement of external winds at roof level. This delivers fresh air to the indoor space while extracting stale and warm air [20]. At nighttime, in the absence of air movement or in low wind conditions, the wind towers operate via the natural buoyancy of thermal forces that is produced by gradient air temperatures between the inside and outside of a building (Fig. 2(a)) [28]. Wind towers in the UAE are distinguished by their partitioned windows, which allow air movement while blocking sand and supporting natural light control (Fig. 2(b)).

Traditional wind towers are typically used to supply ventilation; allow convective cooling at indoor temperatures of $25-35^{\circ} \mathrm{C}$; provide evaporative cooling at temperatures above $35^{\circ} \mathrm{C}$; and cool the building down by either coupling the internal air temperatures to those of the night sky or with the earth in basements, underground tunnels, and streams. Hence, traditional wind catchers are one of the most effective practical approaches to cooling in Gulf houses [29]. 


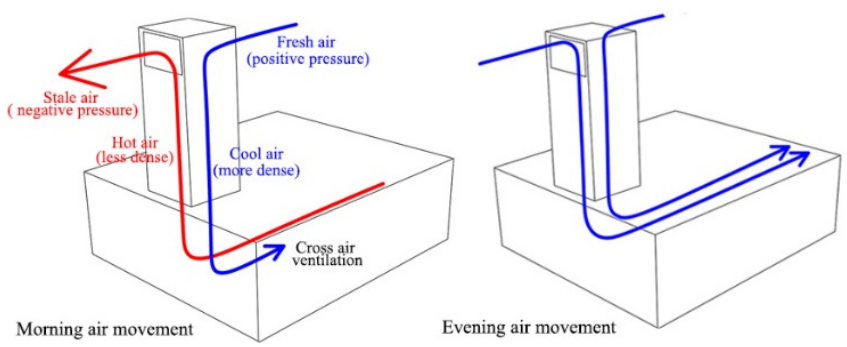

(a)

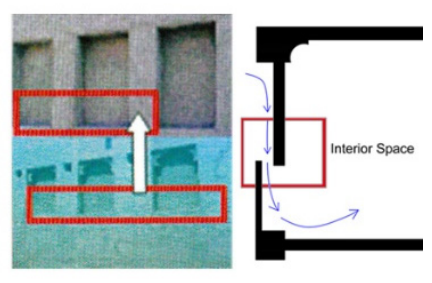

(b)

Figure 2: A diagram that shows ventilation via a wind tower. (a) Air flow in the morning and evening; and (b) Air flow through windows at the top of a wind tower. (Source: Authors, 2019; Dubai Municipality, 2006.)

Wind towers support building sustainability. They act as a natural ventilation system, which plays a significant role in providing optimum indoor air quality and maintaining acceptable thermal indoor and outdoor air masses [30]. Wind towers also support the energy efficiency of buildings and reduce the consumption of cooling energy [21].

Contemporary designers have adapted modern wind towers from the vernacular architecture of the Middle East, as these dramatic architectural features demonstrate the harmony between human-constructed environments and nature [19]. Modern wind towers have been developed to take the advantage of traditional designs and eliminate their limitations, thus adapting them to advanced construction principles and technologies [12]. The utilization of commercial wind towers is now widespread, especially in spaces with high occupant numbers, such as schools and office buildings [31]. The following paragraphs discuss examples of wind towers applied to contemporary designs.

First, "Madinat Jumeirah" - one of the most iconic examples of how heritage and traditional designs can be translated into today's world - describes a characterful collection of residential and commercial buildings surrounded by internal waterways [32]. The architecture includes multiple irregular alleys caused by varying shapes and sizes of the buildings. These alleys also allow for wind circulation, and the varying heights help create shade for neighboring buildings, thus keeping the temperature low. The architectural design relies on wind towers and open courtyards inspired by the bastakiya area of Dubai, which have a positive impact on the interior environment (Fig. 3(a)). The wind towers create a cool microclimate, provides appropriate ventilation, and improves indoor air quality (IAQ).

The second example is "Khalifa Al Tjer Mosque", which is one of the newest sustainable structures built in Dubai, achieving LEED certification in 2016 [33]. The design of the pillar cladding is inspired by traditional wind towers, as observed in its small doors that can be opened onto the roof at the one end, thus operating as a natural stack ventilation method (Fig. 3(b)).

\subsubsection{Courtyards}

Inner courtyards are private spaces surrounded by walls and buildings; they are mostly exposed to the surrounding climate and serve as a link between interior spaces [34]. The primary purpose of the inner courtyard in residential architecture is to provide privacy for the building occupants as they engage in daily activities [35]. Inner courtyards also offer the comforts of natural light, privacy, security, and tranquility to interior spaces [34], [36]. They are one of the most prevalent architectural elements in arid climates, as courtyards alleviate 

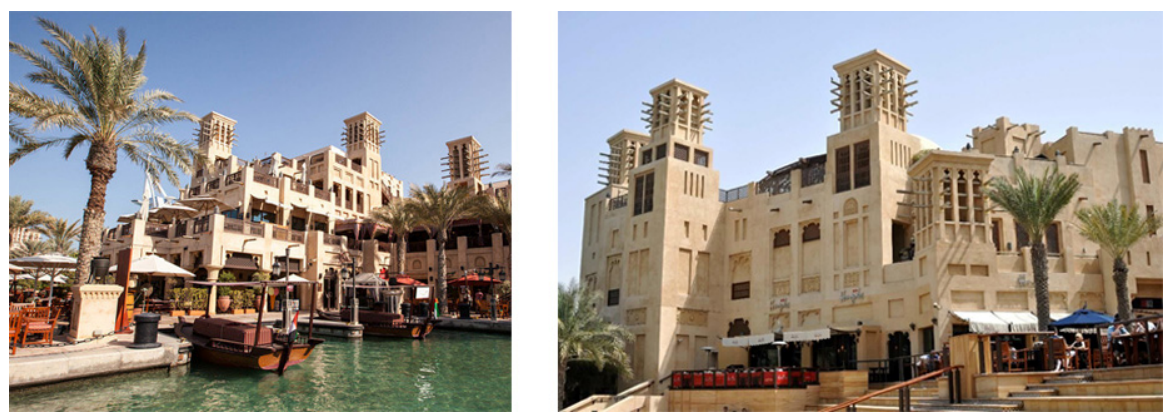

(a)

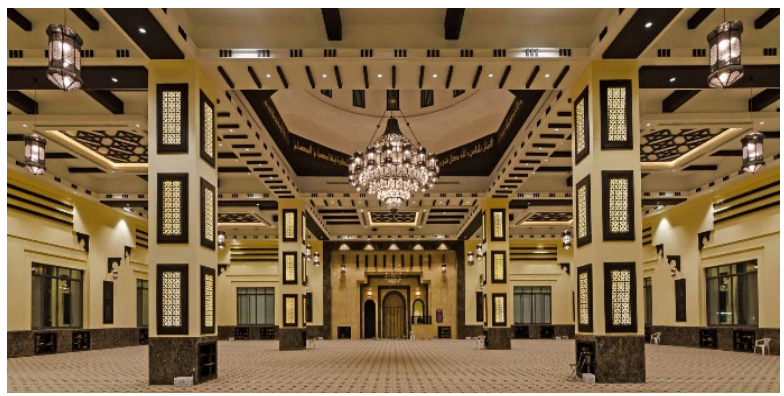

(b)

Figure 3: The application of wind towers in contemporary design. (a) Wind towers in the architecture of "Madinat Jumeirah", Dubai; and (b) Wind towers in the interior of "Khalifa Al Tjer Mosque", Dubai. (Source: Authors, 2019.)

solar overload by creating shaded spaces combined with natural cooling strategies and protection from dust or sand [37]. Courtyard walls feature stones or bricks with suitable thickness to prevent heat transfer from outside. These walls contain windows and openings of limited size, especially those facing the street, which are directed toward the interior courtyard. In addition, they use wooden or gypsum window screens called "Mashrabiya" to create shade and control lighting (Fig. 4) [3].
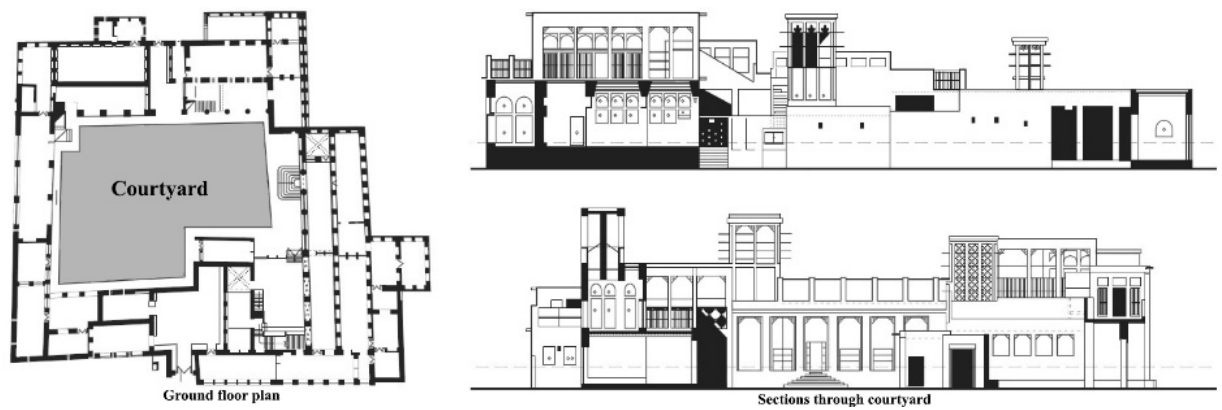

Figure 4: Courtyard plan and section from Sheikh Saeed house. (Source: Dubai Municipality, 2006.) 
The purpose of the courtyard in hot, arid climates is to make use of the great thermal mass of heat stored by its extensive surface area throughout the day to provide warmth during cooler nights. By maximizing the surface-to-volume ratio, the courtyard operates as a heat sink, thus limiting severe temperature stress and reradiating the interior heat into the night air (Fig. 5). The combination of their large surface-to-volume ratio, thermal mass, and shading enhances the thermal performance of the building by creating a framework in which low energy strategies are achievable despite the restraint of air conditioning loads [38]. Traditional houses in the UAE usually take a courtyard configuration with limited rectangular room geometry (average dimensions of large rooms $=3 \times 8 \mathrm{~m}^{2}$ ) [39]. Thus, courtyards are essential in cooling buildings through their creation of a microclimate in between the interior and exterior environment that is extra quiet, clean, and private, especially in hot climates where the form of a building and its environmental performance work in tandem [40].

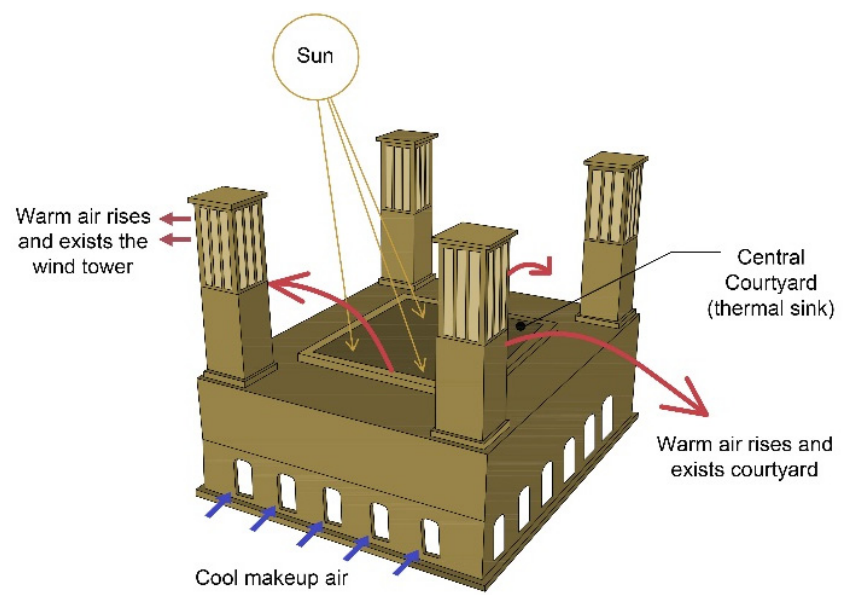

Figure 5: A diagram shows air circulation through the courtyard. (Source: Authors, 2019.)

Besides the environmental advantages of courtyards, their potential psychological impact is frequently highlighted [41]. Courtyards can be considered a sustainable design element, since it contributes positively to occupants' experiences by providing daylight to most of the interior spaces, a connection to nature, and a high level of thermal comfort through its cool microclimate and cross ventilation [40]. This natural ventilation helps enhance the overall quality of the indoor environment. Moreover, the integration of courtyards lead to energy efficient design solutions in all climates, especially in hot, arid, and/or humid climates [38]. Courtyards, in cooperation with wind towers, create a large reduction in cooling energy consumption (Fig. 5).

Traditional courtyards still offer much flexibility to contemporary design solution. There are many examples of courtyards implemented in contemporary architectural and interior design, one of which can be found in the "Sheikh Zayed Mosque" of Abu Dhabi, as shown in Fig. 6(a). Another courtyard in this building has been filled with water, which aids in greater thermal comfort by absorbing excess heat.

Another example is the application of a courtyard in the interior design of "City Centre Mirdif", located in Dubai and designed by RTKL and Holford Associates. Although this courtyard was designed to be covered by glass ceiling as a skylight to support the function of 

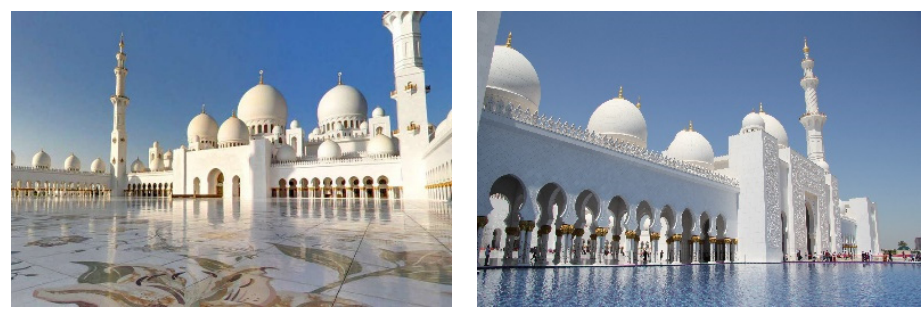

(a)
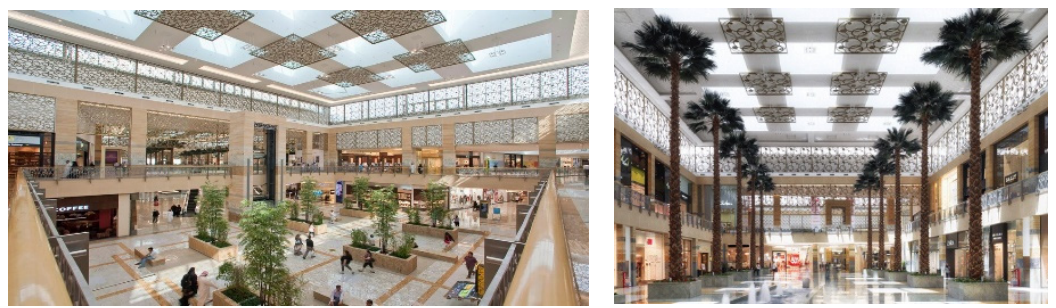

(b)

Figure 6: The application of courtyards in contemporary design. (a) Courtyards in "Sheikh Zayed Mosque", Abu Dhabi; and (b) Inner courtyard of "City Centre Mirdif", Dubai. (Source: Authors, 2019.)

artificial air condition system but it is still offer natural ventilation by opening the windows at the top of the courtyard. In addition, the courtyard still offer for visitors a pleasant experience through the natural day lighting for most of the surrounded interior spaces and connection to nature (Fig. 6(b)).

\subsubsection{Interior treatments and construction materials}

Buildings incorporating wind towers along Dubai Creek were constructed of palm fronds known as Bait Areesh - which was the standard material used to construct homes in the region pre-1900. The coral or sea stone homes of Dubai, locally known as Bait Morjan, were built using local materials such as coral, shell, wooden joists, palm trunks, and woven mats [42], [43]. The walls were built from coral and shell stone extracted from the adjacent creek, cemented together using a mixture of mud, sand, gypsum, and limestone (Fig. 7(a)). Later,

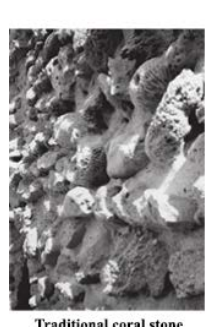

(a)

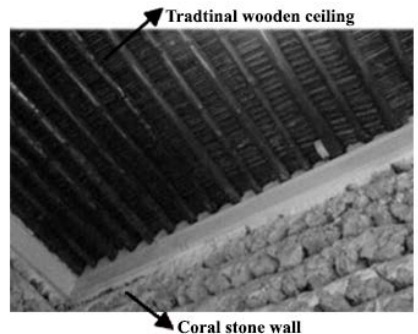

(b)

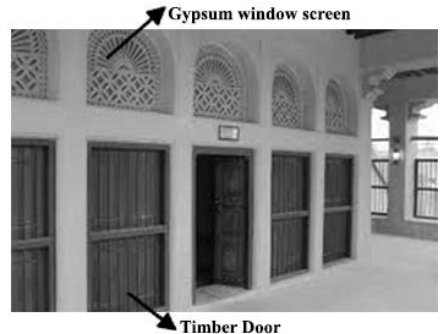

(c)

Figure 7: Interior treatments and construction materials. (a) Coral stone wall; (b) Wooden ceiling; and (c) Gypsum window screen and timber door. (Source: Authors, 2019; Dubai Municipality, 2006.) 
the building was covered with a layer of sand, mud, and rock for added insulation and protection [11]. The wall thickness of such buildings ranges from $0.5 \mathrm{~m}$ (internal wall) to $1.6 \mathrm{~m}$ (external wall), which provides a strong, stable structure with high thermal capacity [44]. The ground floor is made of four simple layers, including a sand layer that covered a mix of gravel and clay, topped with carpets made of palm leaves [11]. The roof was also built in layers, traditionally comprising palm trunks and timber joists, which are covered by woven palm fronds and shielded by gypsum and clay tiles [45] (Fig. 7(b)). The windows feature gypsum screen without glass panels to provide shade, while the doors are made of local timber (Fig. 7(c)) [42].

The construction materials, whether they are made of palm or coral, are considered sustainable since they do not emit any harmful gases, enhance IAQ performance, and are biodegradable [46]. Although, coral was considered a sustainable material during the time of construction, due to the limited population and low consumption, the UAE now prohibits the extraction of coral to protect its marine life. Therefore, coral has been abandoned as a viable construction material. Other traditional materials, such as palm trunks and leaves, are barely used in today's architecture, since they do not fit the tremendous changes to modern construction methods.

\subsubsection{Mashrabiya}

The mashrabiya (window-perforated screen) is an architectural element that covers windows on higher floors, overlooking either the exterior or the interior of the building's courtyard [47]. In addition to its aesthetic appeal and social value, mashrabiya were developed to meet various functions, considering the desert climate of the regions in which it originated [48]. These functions include ensuring privacy; controlling the passage of natural light to protect occupants from the glaring hot sun; and governing climate conditions in the dwelling by controlling airflow, reducing the temperature of air currents, and increasing the humidity of air currents [47], [49]. Moreover, by creating an air draft, mashrabiya are part of a cooling mechanism in connection with wind towers and courtyards [47], [50]. Mashrabiya feature different patterns and materials, such as wood and gypsum, which were developed to satisfy a variety of conditions and functions (Fig. 8) [48].
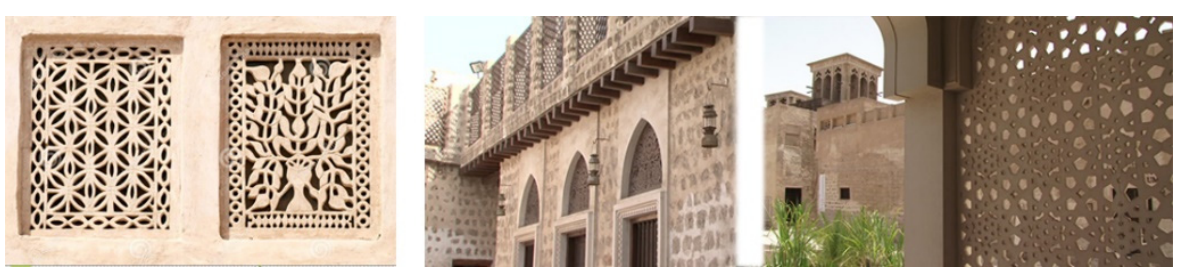

Figure 8: Applications of mashrabiya in Dubai heritage buildings. (Source: Authors, 2019.)

Due to the rapidly developing environment of UAE cities, these window screens have moved beyond the confinements of traditional use, coming into a new role as iconic veils that ornament modern skyscrapers, thus affirming local identity and serving as a shading device to aid cooling. Some contemporary designers have transformed the vernacular mashrabiya structure into high-tech, responsive shading systems [10].

Many projects in the UAE represent a revival of the sustainable usage of mashrabiya, which are explored in the following examples. "Al Bahar Towers", located in Abu Dhabi and designed by Aedas, feature thermo-sensitive screens inspired by the mashrabiya (Fig. 8). 
These screens are integrated into a curtain walling system that has been fixed $2 \mathrm{~m}$ from the main structure, thus acting as a secondary skin that controls the amount of daylight and reduces glare. The screens consist of triangles constructed from fiberglass, which are programmed to open and close depending on the position of the sun [51]. Through this innovative system, solar penetration and the resultant radiation can be mitigated, leading to a reduced energy load for cooling. The south-facing roofs of each tower also incorporate photo-voltaic cells, which generate approximately $5 \%$ of the total required energy from renewable energy sources (Fig. 9) [52].
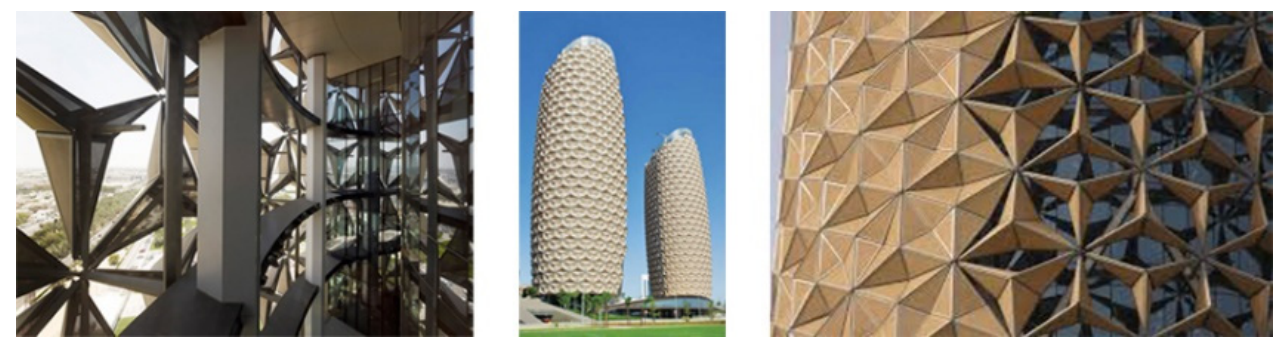

Figure 9: Mashrabiya inspired the automated screens covering "Al Bahar Towers" in Abu Dhabi. (Source: Authors, 2019.)

Mashrabiya have been employed in interior design through a variety of methods. They may be used as staircase railings, wall claddings, and wall partitions, thus controlling the natural illumination of interior environments while providing an aesthetic pattern. The ceiling treatments of "Louvre Abu Dhabi" are considered a perfect example of the creative reinterpretation of vernacular elements in interior design (Fig. 10).

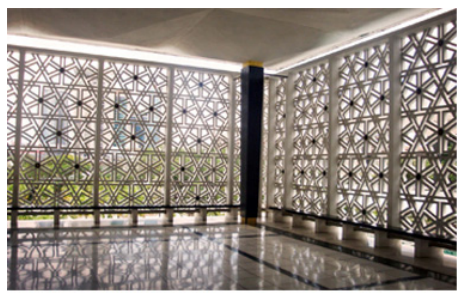

(a)

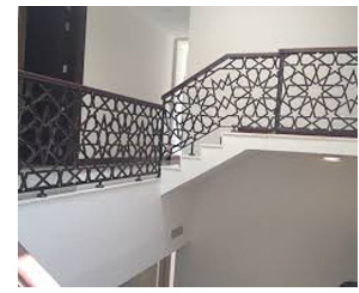

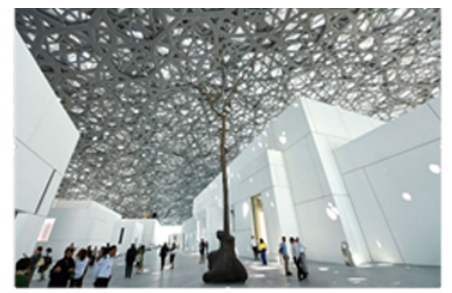

(b)

Figure 10: Mashrabiya applied to interior design solutions. (a) Mashrabiya as wall partitions and staircase railings; and (b) Mashrabiya as ceiling treatments in "Louvre Abu Dhabi". (Source: Jali, 2019; Authors, 2019.)

\section{CONCLUSION}

The various elements of heritage designs in the UAE - developed over years of local architectural wisdom and knowledge - arose from the need to create solutions capable of withstanding the harsh climate of the region while respecting the traditional norms of the society and local socio-economic conditions. The result of this has led to sustainability in the built environment, which is a natural byproduct of the vernacular concept of designing. 
The literature analyzed in this study described the importance of integrating vernacular sustainable techniques, such as wind towers, interior courtyards, and mashrabiya, in modern buildings. Such applications will extend the preservation of heritage found in these elements while reducing the carbon footprint and the negative impacts of energy-driven solutions for ventilation, daylight control, and improving IAQ.

This paper shows that vernacular interior design in the UAE is progressing toward being a successful model in achieving effective contemporary sustainable design that is inspired by local vocabularies of heritage design and emphasizes regionalism.

Interior designers must revive local identities and re-explore the principles of vernacular sustainable solutions by considering its techniques alongside their original design ideals, respecting the requirements of sustainable development, and mixing these principles with contemporary technologies. Modern architecture can make more effective use of vernacular sustainable design approaches, thus creating a more sustainable environment worldwide.

\section{REFERENCES}

[1] Casakin, H. \& Bernardo, F. (eds), The Role of Place Identity in the Perception, Understanding, and Design of Built Environments, Bentham Science Publishers: Sharjah, 2012.

[2] Glassie, H., Vernacular Architecture, University Press: Indiana, 2000.

[3] Ahmed, E.N.E.M., Islamic architectural character (between legitimacy and disparity). Journal of Islamic Architecture, 3(1), pp. 25-38, 2014.

[4] Oliver, P., Built to Meet Needs: Cultural Issues in Vernacular Architecture, Routledge: London, 2007.

[5] Hartel, T., Fischer, J., Câmpeanu, C., Milcu, A.I., Hanspach, J. \& Fazey, I., The importance of ecosystem services for rural inhabitants in a changing cultural landscape in Romania. Ecol. Soc., 19, article 42, 2014.

[6] Adam, R., The Globalisation of Modern Architecture: The Impact of Politics, Economics, and Social Change on Architecture and Urban Design Since 1990, Cambridge Scholars Publishing: Newcastle, UK, 2012.

[7] Aly, S.S.A., Modernization and regionalism: Approaches for sustainable revival of local urban identity. Procedia Engineering, 21, pp. 503-512, 2011.

[8] Haggag, M. \& Rashed, A., Urban conservation in practice: evidence from the United Arab Emirates. Alexandria Engineering Journal, 42(2), pp. 249-261, 2003.

[9] Boussaa, D., Dubai: The search for identity. People, Places, and Sustainability, eds G. Moser, E. Pol, Y. Bernard, M. Bonnes, J. Corraliza \& V. Giuliani, Hogrefe Publishing: Boston, pp. 51-60, 2003.

[10] Abdelsalam, T. \& Rihan, G.M., The impact of sustainability trends on housing design identity of Arab cities. HBRC Journal, 9(2), pp. 159-172, 2013.

[11] Hawker, R., Traditional Architecture of the Arabian Gulf: Building on Desert Tides, WIT Press: Southampton and Boston, 2008.

[12] Jomehzadeh, F. et al., A review on windcatcher for passive cooling and natural ventilation in buildings. Part 1: Indoor air quality and thermal comfort assessment. Renewable and Sustainable Energy Reviews, 70, pp. 736-756, 2017.

[13] Wahid, A., Adaptive vernacular options for sustainable architecture. Journal of the International Society for the Study of Vernacular Settlements, 2(2), pp. 74-85, 2012.

[14] Al Marashi, H. \& Bhinder, J., From the tallest to the greenest-paradigm shift in Dubai. Proceedings of the CTBUH Eighth World Congress, pp. 1-8, 2008.

[15] United Arab Emirates and the 2030 Agenda for Sustainable Development, Federal Competitiveness and Statistics Authority, Secretariat for UAE National Committee on 
SDGs. $\quad$ http://fcsa.gov.ae/en-us/Lists/D_Reports/Attachments/14/UAESDGsEN.PDF. Accessed on: 15 Jun. 2019.

[16] Madichie, N.O., IRENA - Masdar City (UAE): Exemplars of innovation into emerging markets. Foresight, 13(6), pp. 34-47, 2011.

[17] Santamouris, M. (ed.), Advances in Passive Cooling, Routledge: London, 2012.

[18] Zhai, Z.J. \& Previtali, J.M., Ancient vernacular architecture: Characteristics categorization and energy performance evaluation. Energy and Buildings, 42(3), pp. 357-365, 2010.

[19] Bahadori, M.N., Dehghani-Sanij, A. \& Sayigh, A., Wind Towers: Architecture, Climate and Sustainability, Springer: Berlin, 2014.

[20] Iyengar, K., Sustainable Architectural Design: An Overview, Routledge: London, 2015.

[21] Patel, D. \& Rajan, S.T., Design of a passive and wind speed responsive wind catcher for energy efficient buildings. International Journal for Innovative Research in Science and Technology, 1(8), pp. 15-128, 2015.

[22] El-Shorbagy, A.M., Design with nature: Windcatcher as a paradigm of natural ventilation device in buildings. International Journal of Civil and Environmental Engineering, 10(3), pp. 26-31, 2010.

[23] Ionescu, C., Baracu, T., Vlad, G.E., Necula, H. \& Badea, A., The historical evolution of the energy efficient buildings. Renewable and Sustainable Energy Reviews, 49, pp. 243-253, 2015.

[24] Kassir, R.M., Passive downdraught evaporative cooling wind-towers: A case study using simulation with field-corroborated results. Building Services Engineering Research and Technology, 37(1), pp. 103-120, 2016.

[25] Saadatian, O., Haw, L.C., Sopian, K. \& Sulaiman, M.Y., Review of windcatcher technologies. Renewable and Sustainable Energy Reviews, 16(3), pp. 1477-1495, 2012.

[26] Tavakolinia, F., Wind-chimney (integrating the principles of a wind-catcher and a solar-chimney to provide natural ventilation). Master's thesis, California Polytechnic State University, California, 2011.

[27] Hughes, B.R., Calautit, J.K. \& Ghani, S.A., The development of commercial wind towers for natural ventilation: A review. Applied Energy, 92, pp. 606-627, 2012.

[28] Sayigh, A., Sustainability, Energy and Architecture: Case Studies in Realizing Green Buildings, Academic Press: Cambridge, 2013.

[29] Al Sammani, A.M., The sustainable development of local housing units in UAE. Master's thesis, The British University in Dubai, Dubai, 2011.

[30] Weber, A., Sustainable tourism in extreme environments: Lessons from desert regions. Proceedings of the 2nd International Scientific Conference Tourism in South East Europe, pp. 421-434, 2013.

[31] Zhou, J., Zhang, G., Lin, Y. \& Li, Y., Coupling of thermal mass and natural ventilation in buildings. Energy and Buildings, 40(6), pp. 979-986, 2008.

[32] Mirage Leisure and Development, Madinat Jumeirah. www.mirageleisure.com/ projects\#/Madinat-Jumeirah-Resort. Accessed on: 17 Jun. 2019.

[33] US Green Council Building, Leadership in energy and environmental design, Khalifa Al Tjer Mosque LEED certification. www.usgbc.org/ projects/khalifa-mosque-dubaiuae?view=certifications. Accessed on: 17 Jun. 2019.

[34] Edwards, B., Sibley, M., Land, P. \& Hakmi, M. (eds), Courtyard Housing: Past, Present and Future, Taylor and Francis: London, 2006. 
[35] Mortada, H., Traditional Islamic Principles of Built Environment, Routledge: London, 2003.

[36] Attia, S., The role of landscape design in improving the microclimate in traditional courtyard buildings in hot arid climates. Proceedings of the 23rd International Conference on Passive and Low Energy Architecture, pp. 22-24, 2006.

[37] Ratti, C., Raydan, D. \& Steemers, K., Building form and environmental performance: Archetypes, analysis and an arid climate. Energy and Buildings, 35(1), pp. 49-59, 2003.

[38] Aldawoud, A., Thermal performance of courtyard buildings. Energy and Buildings, 40(5), pp. 906-910, 2008.

[39] Al-Sallal, K.A., AbouElhamd, A.R. \& Bin Dalmouk, M., Daylighting performance in UAE traditional buildings used as museums. International Journal of Low-Carbon Technologies, 13(2), pp. 116-121, 2018.

[40] Almhafdy, A., Ibrahim, N., Ahmad, S.S. \& Yahya, J., Courtyard design variants and microclimate performance. Procedia-Social and Behavioral Sciences, 101(8), pp. 170-180, 2013.

[41] Abass, F., Ismail, L.H. \& Solla, M., A review of courtyard house: History evolution forms, and functions. Journal of Engineering and Applied Sciences, 11(4), pp. 25572563, 2016.

[42] Dubai Municipality, Elements of Traditional Architecture in Dubai, Dubai Press: Dubai, 2006.

[43] Ragette, F., Traditional Domestic Architecture of the Arab Region. Edition Axel Menges: Fellbach, 2003.

[44] Faraj, A.H., The potential of integrating PV in the heritage sites: Case study of Dubai Museum. Master's thesis, The British University in Dubai, Dubai, 2015.

[45] Elmasry, S.K., The role of modular construction in the revival of traditional Emirati souks. WIT Transactions on the Built Environment, vol. 171, WIT Press: Southampton and Boston, pp. 75-85, 2017.

[46] Rashdan, W. \& Ashour, A.F., Criteria for sustainable interior design solutions. WIT Transactions on Ecology and the Environment, vol. 223, WIT Press: Southampton and Boston, pp. 311-322, 2017.

[47] Mohamed, J., The traditional arts and crafts of turnery or mashrabiya. Master's thesis, Graduate School, Rutgers University-Camden, New Jersey, 2015.

[48] Karamata, B. \& Andersen, M., Concept, design and performance of a shape variable mashrabiya as a shading and daylighting system for arid climates. Proceedings of the 30th PLEA Conference, Sustainable Habitat for Developing Societies, pp. 344-351, 2014.

[49] Giovannini, L., Verso, V.R.L., Karamata, B. \& Andersen, M., Lighting and energy performance of an adaptive shading and daylighting system for arid climates. Energy Procedia, 78, pp. 370-375, 2015.

[50] El Basyouni, M., Integrating features of Islamic traditional home and smart home. Journal of Islamic Architecture, 4(3), pp. 114-123, 2017.

[51] Attia, S., Evaluation of adaptive facades: The case study of Al Bahr Towers in the UAE. QScience Connect, 2017(2), pp. 1-12, 2018.

[52] Al-Kodmany, K.M., Green towers and iconic design: Cases from three continents. International Journal of Architectural Research, 8(1), pp. 11-28, 2014.

[53] Jali Designs, Mashrabiya in modern interior design (Pinterest post). www.pinterest.com/pin/226517056236322078/. Accessed on: 19 Jun. 2019. 